Başvuru Tarihi: 30.11.2016 Received Date: 30.11 .2016

Yayına Kabul Tarihi: 26.01.2017 Accepted Date: 26.01.2017

Yayınlanma Tarihi: 30.01.2017 Published Date: 30.01.2017

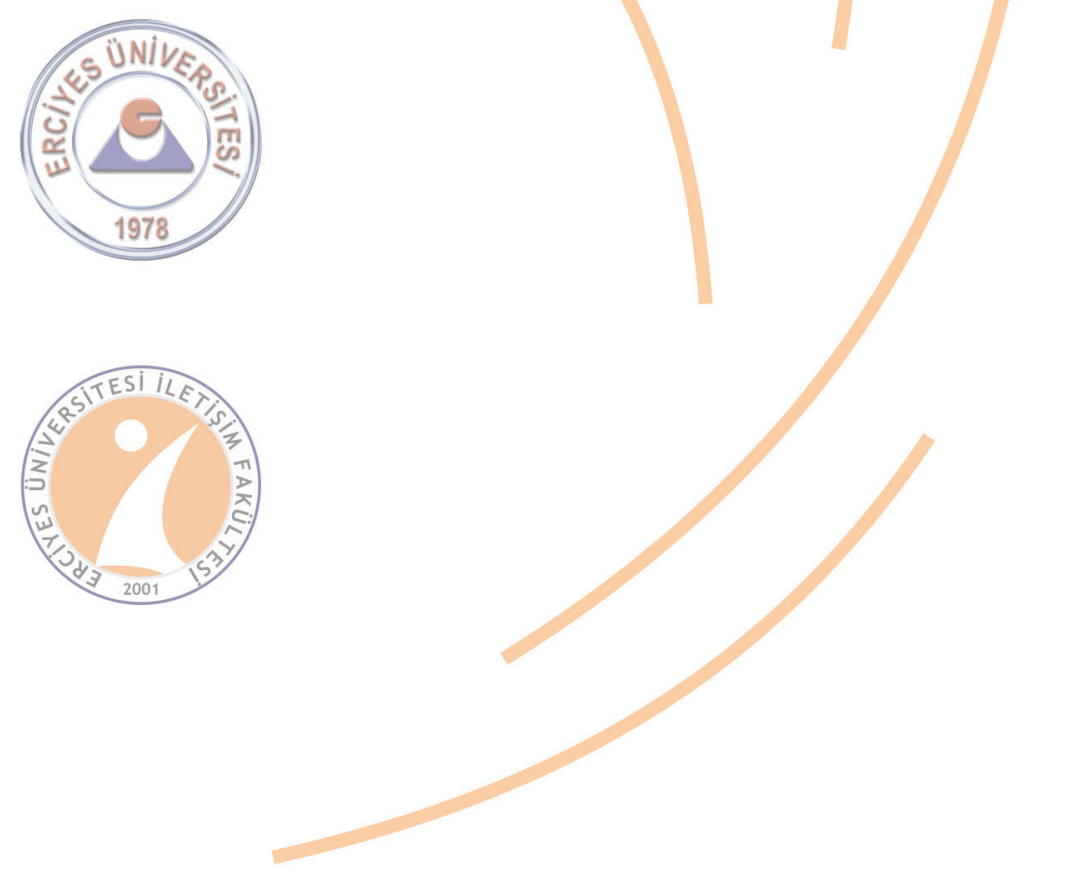

akademia 
ISSN:1308-3198

Erciyes İletişim Dergisi "akademia" 2017

Cilt (Volume): 5, Sayı (Number): 1, (222-234)
Gizem MELEK (Öğr. Gör. Dr.)

Yaşar Üniversitesi İletişim Fakültesi gizem.melek@yasar.edu.tr

Huriye TOKER (Doç. Dr.)

Yaşar Üniversitesi İletişim Fakültesi

huriye.toker@yasar.edu.tr

\section{ŞİDDET, DEMOKRASİ VE TERÖR BAĞLAMINDA ANA AKIM MEDYANIN ANALIZI: 15 TEMMUZ DARBE GIRIŞIMI}

\section{$\ddot{O} z$}

Son 60 yılda iki askeri darbe, iki kez muhtıra ile hükümetin istifaya zorlanması ve iki de başarısız darbe girişimi gören Türkiye Cumhuriyeti, 15 Temmuz 2016'da yeni bir darbe girişimiyle daha karşı karşıya kalmıştır. Bastırılan bu darbe girişimi medyada çok yoğun bir şekilde haberleştirilmiş, kısa süre içinde yüzlerce haber ana akım medyada yer bulmuştur. $\mathrm{Bu}$ gerçeklikten yola çıkan çalışmada, ideolojik eğilimleri ve seslendiği okuyucu kitlesi farklılaşan dört ana akım medya kuruluşunun web sitelerinde yer alan haberler incelenmiștir. Alexa verilerine göre darbe girişimine ilişkin ilk üç günü kapsayan 15 ile 17 Temmuz 2016 tarihleri arasında Türkiye'de en çok tıklanan ana akım gazete web sitelerinden olan Hürriyet, Milliyet, Cumhuriyet ve Sabah kuruluşları çalışmaya dâhil edilmiş ve üç günde bu haber kuruluşlarından toplam 760 haber toplanmıștır. Elde edilen haberler içerik analizi yöntemiyle incelenmiş haber tema ve aktörlerine ilişkin bulgular tartışılmıștır. Sonuçlar medyanın darbe girișimini şiddet, demokrasi ve terör üçgeninde ön plana çıkardığını göstermiștir. Yine medyanın kırılgan dönemlerde siyasi ve bürokratik kaynaklara mikrofonu uzatırken, sivil toplumu ve uzmanları görmezden geldiği de saptanmıştır.

Anahtar Kelimeler: 15 Temmuz, Askeri Darbe, Darbe Girișimi, Gündem Belirleme, Ana akım Medya, Medya Analizi, Şiddet, Demokrasi, Terör.

\section{AN ANALYSIS OF THE MAINSTREAM MEDIA WITHIN THE CONTEXT OF VIOLENCE, DEMOCRACY AND TERROR: 15 JULY COUP ATTEMPT}

\section{Abstract}

The Republic of Turkey, a country which had seen two military coups, two memorandums to force the government to resign and two failed coup attempts in the past 60 years, faced a new coup attempt on July 15, 2016. This coup attempt, which was suppressed, was covered intensively on media and in a short period of time hundreds of news items were found in the mainstream media. Therefore, in this study news stories from the websites of four mainstream media company all of which have different ideological tendencies and audience, were examined. Hürriyet, Milliyet, Cumhuriyet and Sabah which were the most visited news websites in Turkey during the first three days of the coup attempt, 15-17 July, according to Alexa, were included in the research and in total 760 news stories were collected. Later, a content analysis was conducted and the themes of the news items and sources were determined. The results showed that the media featured the coup attempt within the triangle of violence, democracy, and terror. The results also revealed that during the times of fragility, the media tend to extend the microphone to political and bureaucratic figures and ignore the NGOs and specialists.

Keywords: 15 July, Military Coup, Coup Attempt, Agenda-Setting, Mainstream Media, Media Analysis, Violence, Democracy, Terror. 


\section{Giriş}

McCombs ve Shaw 1972'de temellerini attıkları gündem belirleme kuramı ile medyanın ön plana çıkardığ 1 konuların kamuoyu gündemini oluşturduğunu tespit ettiler. Evreleri sıralı bir şekilde gelmemekle birlikte gündem belirleme kuramı tarihsel süreçte beş evreye ayrılmıştır. Bunlar birinci aşama, ikinci aşama, yönelim ihtiyacı, öne çıkarma ve medya arası gündem belirleme şeklindedir (Lee, 2005). Kuramın birinci aşaması her zaman nesne üzerinde yoğunlaşmış ve belirginlik konusunun medyadan kamuoyuna doğru aktarıldığ 1 kısmı ile ilgilenmişti. Bu nesneler politika, markalar, sorunlar olabilmektedir (Lee, 2005). McCombs ve Shaw'ın yaptığ 1 Chapel Hill araştırmasında nesne politikaydı (1972). İlerleyen yıllarda yapılan çalışmalar medyada gündem belirlemenin ikinci aşaması olduğu fikri üzerine yoğunlaşmıştır. İlk aşamada gündem belirleme belirtildiği gibi nesne üzerinden gitmişken ikinci aşamada ise gündem belirleme nesne hakkında ne söylendiği üzerine odaklanmıştır (McCombs, 2002; McCombs, 2005). İkinci aşamada nesnenin medyada atfedilme şekli ve bu atıfın kamuoyu algısı üzerindeki etkisi ön plandadır (Lee, 2005). Yani, birinci aşama gündem belirleme "ne düşünmemiz gerektiğini" söylerken ikinci aşama gündem belirleme atıf kullanımıyla "nasıl düşünmemiz gerektiğini” söyler (Cohen, 1963, 13; Lee, 2005; McCombs ve Bell, 1996).

McCombs ve diğerlerine göre "atıflar her nesnenin resmini tamamlayan karakter ve özelliklerdir. Ana akım medya bir nesneyi tanıttığında bize aynı zamanda bu nesnenin atfiyla ilgili bir şeyler de söyler" $(2000,78)$. McCombs ve Shaw'ın araştırmasında belirginlik konusunun medyadan kamuoyuna doğru olduğu hipotezi üzerinde durulmuştu (1972). Benzer şekilde ikinci aşama gündem belirlemede ise medyanın haberlerde kullandıkları atıfların kamuoyunda nasıl popüler hale geldiği üzerinde durulmuştur (Kiousis ve diğerleri, 1999; Lee, 2005).

Gündem belirleme çalışmaları geliştikçe araştırmacılar gündem belirleme etkilerinin ne koşullarda belli bireyler üzerinde daha etkili olduğunu araştırmaya başlamıştır. "Neden insanların bilgi arayışında oldukları ve bazı kişilerin diğerlerine göre gündem belirleme etkilerine daha açık olduklarını anlamak için psikolojik bir açılama" olarak tanımlanan yönelim ihtiyacı, insanların bilgi edinmelerinin arkasında yatan motivasyonu araştırmaktadır (Matthes, 2008, 440). Weaver, yönelim ihtiyacını "yakınlık ilgisi" ve "belirsizlik" olmak üzere ikiye ayırmıştır. Yakınlık ilgisi insanların kendileriyle bir ilişki veya alaka kurmadığı bir bilgi ile ilgilenmediği anlamına gelmektedir. Belirsizlik ise insanların bir konu hakkında ihtiyacı olan bilgiyi edindikleri takdirde konuya yönelik ilgilerini kaybettikleri ve konunun onlar için belirsizleştiği anlamına gelmektedir (1977). 2011'de Chernov ve diğerleri yönelim ihtiyacı ve gündem belirleme üzerine yaptıkları bir çalışmada yakınlık ilgisi ve belirsizlik temelli yönelim ihtiyacının gündem belirlemeyi önceden tahmin etmeye yaradığını kanıtladı. Araştırmacılar ayrıca yönelim ihtiyacı arttıkça gündem belirleme etkisinin yükseldiğini de tespit ettiler $(2011,151)$.

Medyanın "bazı noktaları abartırken bazılarını ise görmezden gelmek" suretiyle belli bir konuyu ön olana çıkarıp imaj yaratma süreci olarak tanımlanan "öne çıkarma" ise gündem belirlemenin dördüncü aşaması olarak karşımıza çıkmaktadır (Severin ve Tankard, 2001, 240). Kim ve diğerlerinin atıf ve öne çıkarma arasındaki bağlantıyı araştıran bir çalışması ile "öne çıkarma" gündem belirlemenin bir aşaması haline gelmiştir (2002).

Gündem belirleme araştırmaları ilk yıllarda genellikle kamuoyu gündemini belirleyen unsurlar üzerine yoğunlaşmıştır. Ancak daha yeni çalışmalarda ise medyanın gündemini belirleyen unsurları bulmaya odaklanılmıştır (McCombs ve Shaw, 1993). Araştırmacılar medya kuruluşlarının birbirlerinin gündemini etkilemek suretiyle medya arası gündem belirleme yaratabildiğini ortaya koymuştur (Roberts ve diğerleri, 2002).McCombs ve diğerleri medya arası gündem belirlemeyi bir medya kuruluşunun diğeri üzerindeki etkisi olarak tanımlamıştır (2000).Reese ve Danielian da yaptıkları araştırmada tüm haber kuruluşları arasında en büyük etkiye The New York Times gazetesinin sahip olduğunu saptamıştır (1989).

Medya arası gündem belirleme üzerine yapılan çalışmalar internetin gitgide daha geniş kitlelere yayılmasıyla ana akım medya ile internet ve sosyal ağlar arasındaki ilişkiyi anlamaya 
yönelmiştir. 2010'da Matthew Kushin The New York Times gazetesinin online versiyonu ile sosyal paylaşım sitesi Twitter arasında medya arası gündem belirleme etkisi olup olmadığını araştırmıştır. Çalışmanın sonunda bazı durumlarda tersi olmakla birlikte iki platform arasındaki etkinin yönü ağırlıklı olarak sosyal medyadan ana akım medyaya doğru bulunmuştur (2010). Her ne kadar net bir gündem belirleme etkisi bulunmasa da bu araştırma sosyal medya ve ana akım medya arasındaki gündem belirleme ilişkisini anlama açısından bir köprü oluşturmuştur. Sosyal ağlar ve ana akım medya arasındaki ilişkiye dair araştırmalara uluslararası bir perspektif katmak amacıyla benzer bir çalı̧̧mayı Gizem Melek Türkiye'de Hürriyet gazetesinin web sitesi ile Twitter arasında yapmıştır (2015). Çalışmada hem bu iki platform arasında bir ilişki olup olmadığına hem de ilişki varsa bunun ne yönde olduğuna bakılmıştır. Çalışma Kushin'in araştırmasına benzer bir sonuç vermiş olup karşılıklı net bir gündem belirleme etkisi bulunamamakla beraber etkinin yönünün Twitter'dan Hürriyet'e doğru olma eğiliminde olduğu saptanmıştır (Melek, 2015). Aynı zamanda bu çalışma her ne kadar gündemi belirlemese de Twitter'ın ana akım medya üzerinde hafife alınamayacak bir etkisi olduğunu da kanıtlamıştır.

Akademik çevreler gündem belirleme kuramına yaptığı katk1 ve kaçınılmaz bağlantısı nedeniyle, çerçeveleme yaklaşımına ciddi bir onay vermişlerdir (Lee, 2005). Belli bir problem tanımı, gündelik yorumlama, ahlaki değerlendirme ve/veya çözüm önerisi gibi durumları ön plana çıkarmak için bir iletişim metninde algılanan gerçekliğin bir kısmının seçilip daha belirgin hale getirilmesine çerçeveleme denmektedir (Entman, 1993, 52).

Gündem belirleme ve çerçeveleme yaklaşımları 1şığında pek çok araştırma yapıllmıştır. $\mathrm{Bu}$ araştırmaların büyük kısmı kamuoyunun belirli konulara ilişkin bakış açılarını, medyanın belirlediği önceliğe göre sıraladıklarını göstermektedir (Scheufele, 1999). Ryan, genellikle haberlerin seçimi, tonu ve sunuş şeklinin önemine vurgu yaparak medya çerçevesini "haberin nasıl oluşturulduğu, habere ilişkin verilerin nasıl seçildiği, bir araya getirildiği ve halka duyurulduğu belirleyicidir" şeklinde açıklar (1991, 53). Gitlin de medyanın kullandığı çerçeveler ile ideolojinin yaratıcısı ve taşıyıcısı olduğunu belirtir (1980). Goffman'a göre bireyler yeni bilgiyi yorumlayıcı şemalar veya geçmişte kurulan çatı ile kategorize eder ve anlamlandırır (1974). Buna benzer bir yorumu Tankard ve diğerleri (1991) de yaparak medya çerçevesini haber içeriğinin ana düzenleyici düşüncesi olarak tanımlar. Bahsedilen içerikte haberin metninde öne çıkarılacak veya metne dâhil edilmeyecek öğeler belirlenir.

Takeshita ise çerçeveleme etkisinin gündem belirleme etkisine göre bir adım daha ilerde olduğuna vurgu yapar:

Teoride gündem belirleme etkisi bilişsel olarak karakterize edilirken, çerçeveleme etkisi ise bundan daha fazladır. Genellikle referans verilen "insanlara ne düşüneceğini değil neyin hakkında düşüneceğini söyler" olarak bilinen gündem belirleme etkisi tanımına baktığımızda temel gündem belirleme sürecinin bilişsel boyutta kaldığı görülür $(2006,278)$.

Kısaca çerçevelemeyi medya tarafından belirlenen temalarla belli bir konunun bazı özelliklerinin öne çıkarılması şeklinde tanımlamak mümkündür (Weaver, 2007; Scheufele ve Tewksbury, 2007). Bu durumda her konunun çoklu niteliğe sahip olması söz konusudur (McCombs, 2004). Birden fazla özelliğe sahip konunun özelliklerinden seçilen bir tanesine yapılan atıfla medya hem ne hakkında konuşacağımızı hem de nasıl konuşacağımızı belirlemiş olur (McCombs ve Shaw, 1993). Weberling (2012) bir çalışmasında bir sivil toplum kuruluşunun e-posta mesajlarına niteliksel içerik analizi uygulamış, metin içindeki temalara ve çerçevelere bakarak gündem belirleme ve çerçeve analizi yapmıştır. İncelemeler sonucunda "eylem", "yatırım" ve "aciliyet" olmak üzere üç ana çerçeve ortaya koyan Weberling, çalışmanın kurumsal e-postalarda bulunan çerçeveleri ve stratejileri açığa çıkararak mevcut araştırmalara yeni bir kademe eklediğini ifade etmiştir (2012). Sonuç olarak gündem belirlemenin birinci aşamasında konunun sadece medyada yer alıp almamasıyla ilgilenilirken çerçevelemede ise anlatım şekli, öne çıkarılan veya daha sık vurgulanan kısımları odak noktasındadır. 
Yukarıda anlatılan, $1968^{\prime}$ den beri yapılan tüm bu çalışmalar, medyanın hem kamuoyu gündemini belirlediğini, hem de kamuoyunun yaşanan olayları algılama biçimini etkilediğini ortaya koymuştur. Yani medya hem halkın hangi konuları konuşacağını hem de bu konulara ait nasıl bir bakış açıları olacağını belirlemektedir. Buradan yola çıkarak bu çalışmada ana akım medyanın Türkiye'de son yıllarda yaşanan en büyük siyasi olaylardan biri olan 15 Temmuz darbe girişimine hangi çerçeveden baktığı, nasıl bir bakış açısıyla haberleştirdiği tespit edilecektir. Zira çalışmanın ana amacı medyanın 15 Temmuz'u hangi bakış açısı ve temaları ön plana çıararak kamuoyuna duyurduğunu irdelemek ve tespit etmektir. Çalışmanın sonunda ortaya çıan veriler gelecekte yapılacak gündem belirleme çalışmalarına da yardımcı olup ışık tutmayı amaçlamaktadır. İleriki çalışmalarda kamuoyunun 15 Temmuz'u algılama biçimi de araştırıldığ 1 takdirde mevcut çalışmanın verileri ışığında medyanın öne çıkardığı temaların halkın algısını ne biçimde etkilediği anlaşılabilecektir.

Türk siyasal yaşamında sıklıkla gündeme gelen asker-sivil ilişkileri ve askeri darbe kavramları geçtiğimiz 15 Temmuz'da gerçekleşen darbe girişimi süreciyle yeni bir boyut kazanmıştır. Söz konusu gece İstanbul'da Boğaziçi Köprüsü'nün bir grup asker tarafindan trafiğe kapatılması ile başlamış, Ankara'da jetlerin gece boyunca yaptığı alçak uçuş, TRT'ye el konularak bildiri okunması, Ankara Gölbaşı Özel Harekat Daire Başkanlığı'nın F16'larca bombalanması ve pek çok polisin yaşamını yitirmesi ve sokağa çıkma yasağı ilan edilmesiyle devam etmiştir. Başkent sokaklarında tankların görülmesi, tank atışlarıyla Ankara Emniyeti'nin zarar görmesi, Marmaris'te bulunan Cumhurbaşkanı Erdoğan'ın İstanbul'a giderken F-16'lar tarafından sıkıştırılması, TBMM'nin bombalanması gibi olaylarla gerçekleşen darbe girişimi ülkede kaosa neden olmuştur. İçişleri Bakanı Efkan Ala'nın açıklamasına göre 5 bin 171 kişi gözaltına alınmış, 16 bin 899 kişi tutuklanmış, 76 bin 100 kişi görevden uzaklaştırılmıştır ("Efkan...", 2016). Darbe girişimi sırasında 179 sivil, 62 polis ve 5 asker olmak üzere toplam 246 kişi yaşamını yitirmiştir (Özkan, 2016)

Tarihsel sürece baktığımızda Türkiye'de demokrasiye geçiş çeşitli girişimlerden sonra 1945 yılında başlamış, 14 Mayıs 1950 seçimleriyle ise hız kazanmıştır (Kalaycıoğlu, 2008). Sonrasında ilk kez bir askeri darbe 27 Mayıs 1960'ta gerçekleşmiş ancak 1961'de seçimler yapılarak tekrar demokratik yaşama geçilebilmiştir. Bu sürecin devamında 1962 ve 1963 'te gerçekleştirilen iki askeri darbe girişimi ise bastırılmıştır. Sonrasında sırasıyla 12 Mart 1971 muhtırası, 12 Eylül 1980 darbesi, 28 Şubat süreci olarak adı geçen 1997 MGK bildirisi gibi çeşitli dönemlerde ordu hükümeti istifaya zorlamış veya yönetime el koymuştur.

Darbeler mevcut hükümet liderlerinin şiddet kullanılarak veya şiddet kullanma tehdidiyle bir güç birliği tarafından hukuk dışı yollardan değiştirilmesi girişimi olarak tanımlanmaktadır (Huntington, 1969). Huntington'a göre darbelerde şiddet kullanımı ve katılımcılar azdır; ancak katılımcılar hali hazırda siyasal sistem içinde belli bir güç tabanına sahiptirler (1969).

Araştırmacılar ülkelerin gelişmişlik düzeyiyle askeri darbe yaşanması ihtimali arasında ters orantı kurmaktadır (Duverger, 1965). Duverger'e göre bir ülkenin gelişmişlik düzeyi arttıkça, askeri darbe olasılığ ${ }_{1}$ azalmaktadır. Ancak böyle bir olasılık gerçekleştiğinde ise askeri darbenin gerici olma ihtimali de yükselir (1965). Duverger aynı şekilde geri kalmış ülkelerde askeri darbe ihtimalinin daha yüksek olduğunu ve gerçekleşmesi durumunda bu tür darbelerin ilerici olma ihtimalinin ise yükseldiğini savunur (1965). Gelişmişlik düzeyi orta seviyelerde olan ülkelerde de ordunun yönetime el koyma ihtimalinin yüksek olduğu iddia edilebilir; ancak bu ülkelerdeki darbelerin ilerici veya gerici olma ihtimalleri eşittir. Arjantin, Brezilya, Türkiye gibi ülkeler bu gruba dâhil edilebilir (Güler, 2006).

Türkiye'de geçmişte yaşanan darbelerle karşılaştırıldı̆̆ında 15 Temmuz darbe girişimi, şiddet tehdidi ve şiddet temsilinin daha ön plana çıkmış olması açısından farklıdır. Bu nedenle medyada bu konu gündem belirleme kuramı çerçevesinde toplumsal tartışma alanında beklenenden daha uzun süre canlı tutulmuştur. 
"Başarısız darbe girişimi", "girişim", "kalkışma", "terör eylemi” gibi ifadelerle adlandırılan eylemin üzerinden yalnızca yedi ay geçmiş olduğu için bu girişim henüz bilimsel araştırmalara yeni yeni konu olmaya başlamıştır. Konuyla ilgili ilk araştırmalardan olan bu çalışmamı 15 Temmuz darbe girişimine ilişkin medya evreninden yazılı basını ele almakta, ideolojik eğilimleri ve seslendiği okuyucu kitlesi farklılaşan dört gazetede yer alan haberleri analiz etmektedir. Bu çerçevede çalışma, 15-17 Temmuz arasında çıkan haberlerin nitel ve nicel içerik analizini yaparak yaşanan olayın resmini çekmek, anlamak ve anlatmaya çalışmak amacındadır. Bu süreçte ana akım medyada konuyla ilgili aralıksız haber geçilmiş ve çok kısa süreler içinde yüzlerce haber yayınlanmıştır. Çalışma ana akım medyada yer alan haberlerin hangi bakış açısıyla yansıtıldığı, hangi kişi ve/veya kuruluşların sıklıkla haberlerde yer aldığ 1 noktasına odaklanmaktadır. Bununla beraber farklı ideolojilere sahip medya kuruluşlarının darbe girişimini farklı açılardan görüp görmediği, farklı temalara yoğunlaşıp yoğunlaşmadığı da ortaya çıkarılmak istenmiştir. Bu noktaya 1şık tutulduğu takdirde yukarıda da belirtildiği gibi gelecek çalışmalarda kamuoyunun 15 Temmuz'u algılama biçimi de araştırıldığı takdirde mevcut çalışmanın verileri ışı̆̆ında medyanın öne çıkardığı temaların halkın algısını ne biçimde etkilediği anlaşılabilecektir. Yani bu çalışma bu doğrultudaki ilk adımdır.

Yukarıda da belirtildiği gibi çalışmanın amacı 15 ile 17 Temmuz arasında medyada çıkan haberlere nitel ve nicel içerik analizini yaparak medyanın darbe girişimini anlatırken öne çıkardığı temaları, dolayısıyla medyanın 15 Temmuz'u kamuoyuna aktardığı bakış açısını tespit etmektir. Çalışmanın bir diğer amacı da yapılan haberlerin hangi kaynaklara dayandırıldı $\breve{1} 1$ ve hangi kişi/kuruluşların ön plana çıkarıldığını irdelemektir. Bu doğrultuda dört temel araştırma sorusu ortaya çıkmaktadır:

1. Medya darbe girişimini haberleştirirken konuyu hangi temalar çerçevesinde ön plana çıkarmıştır?

2. Farklı ideolojilere sahip medya kuruluşları darbe girişimini farklı bakış açılarıyla mı haberleştirmiştir?

3. Medya yaptığı haberleri hangi haber kaynaklarına dayandırmıştır?

4. Medya bu tür kaotik durumlarda resmi kaynaklara mı yoksa konunun profesyonellerine mi başvurmaktadır?

\section{Araştırmanın Yöntemi}

İnsan iletişiminin uygulamalarını, sebep ve sonuçlarını açıklamaya çalışması, genellemeler yapabilmesi açısından bu çalışmada analiz metodu olan niteliksel ve niceliksel içerik analizi kullanılmıştır (Anderson, 1987, 89). İçerik analizi "sınırları belirlenmiş, kontrollü ve tümdengelime dayalı okuma aracı olarak" nitelendirilmekte (Berelson, 1952, 1) ve yöntem söylem örneklerinin çözümlenmesi esasına dayanmaktadır. 15 Temmuz darbe girişimi de seçilen medya örneklemi üzerinden analiz edilerek bazı çıkarımlar yapılacaktır.

İçerik analizi yönteminin niceliksel olarak verilerin ifade edilebilmesi, tarafsızlığın korunabilmesi için temel koşulları olan örneklemin seçilmesi, analiz birimini saptanması ve kategorilerin belirlenmesi bu çalışmada da uygulanmış, araştırmanın geçerlilik ve güvenirliğini destekleyecek şekilde nedensellik ilişkisiyle belirlenmiştir. Elde edilen sayısal veriler niteliksel bulgular ile de yorumlanmış ve desteklenmiştir.

İncelenen konunun haber değerinin oldukça yüksek olması ve haberin sosyal kurum olarak merkezi rolünü koruduğu yazılı basının web sitelerine odaklanılarak medya analizi gerçekleştirilmiştir.

Yukarda bahsedilen gündem belirleme ve çerçeveleme kuramlarının argümanları doğrultusunda mevcut araştırmada 15 Temmuz darbe girişimi sürecinde Türkiye'de en çok tıklanan ana akım gazete web sitelerindeki haberlere içerik analizi yapılmıştır. Çok yoğun haber yapılan ilk üç gün boyunca (15-17 Temmuz 2016) farklı medya kuruluşlarının öne çıkardığı temalar tespit 
edilerek ampirik verilerle incelenmiştir. Aynı şekilde medya kuruluşlarının haberlerine dayanak gösterdikleri kaynaklar ve aktörler de tespit edilerek aktör çeşitliliği irdelenmiştir.

Olayın başladığ 1 günden itibaren ilk üç gününde farklı ideolojik eğilimlere, sahiplik yapısına ve yayın politikalarına sahip ana akım medya kuruluşları olan Hürriyet, Milliyet, Sabah ve Cumhuriyet gazetelerinin web siteleri örnekleme dâhil edilmiştir. Bu haber kuruluşlarının web siteleri küresel olarak web sitesi trafiği analizi eden Alexa'nın verilerine göre o dönemde en çok tıklanan haber siteleri olmuştur (Alexa, t.y.).

Üç günlük veri toplama sürecinde Cumhuriyet'ten 200, Sabah'tan 136, Hürriyet'ten 202, Milliyet'ten ise 222 olmak üzere toplam 760 haber toplanmıştır. Öncelikle bir Harvard Üniversitesi projesi olan açık kaynak kodlu içerik analizi yazılımı Yoshikoder (Lowe, 2015) ile 760 habere ön analiz yapılarak öne çıkan kelimeler arasından anahtar kelimeler belirlenmiş ve bir codebook oluşturulmuştur. Bu anahtar kelimeler, demokrasi, şiddet, din, terör, milliyetçilik ve ekonomi olmak üzere 6 ana tema altında tanımlanmıştır. Söz konusu 6 tema ve her temayla ilişkili anahtar kelimelerden oluşan codebook, Yoshikoder'a tek tek girilerek bir sözlük oluşturulmuştur. Analizde hata yapmamak için sözlük oluşturulurken temalar altında tanımlanan tüm anahtar kelimelerin tek tek hangi bağlam içinde kullanıldıkları kontrol edilmiştir. $\mathrm{Bu}$ bağlamda vurgulanması gereken nokta da terör ve şiddet temalarındaki ayrımdır. Terör teması, darbe girişimini gerçekleştirdiği ifade edilen Gülen cemaati ve bu cemaatle bağlantılı kişilerin FETÖ isimli örgüt üyesi olduğu ve gerçekleştirdikleri darbe girişiminin de bir terör eylemi olduğu vurgusuyla öne çıkarılan haberleri kapsamaktadır. Şiddet ise bu süreçte sokaklarda yaşanan şiddet olaylarının, yani askerlere yönelik linç girişimlerinin, gözaltında işkence iddialarının ve darp konularının odağa alındığı haberleri kapsamaktadır. Oluşturulan sözlükle yapılan içerik analizi sonucunda darbe girişimi haberlerinde medyanın öne çıkardığı temalara ait frekans dağılımı elde edilmiş ve ardından her temanın her bir medya kuruluşunda gün gün temsil edilme oranlarına dair yüzdeler hesaplanmıştır (bknz. Tablo 1).

\section{Bulgular}

Medya gündeminin büyük kısmını kapsayan darbe girişimi haberleri Hürriyet Gazetesi web sitesinde ilk gün yüzde 50 oranında demokrasi teması ile haberleştirilirken, bunu yüzde 25 oranıyla şiddet olayları, yüzde 20 oranıyla milliyetçilik ve yüzde 5 oranıyla da terör temaları takip etmiştir. Din ve ekonomi temalarına ait bir veri ilk gün için Hürriyet’te yer almamıştır.

Milliyet Gazetesi web sitesinde ise darbe girişimi ilk gün yüzde 85.71 gibi yüksek bir oranda şiddet olayları temasıyla haberleştirilirken bunu yüzde 14.29 ile oranıyla milliyetçilik teması takip etmiştir. Milliyet’te ilk gün diğer temalara ait bir veri yer almamıştır.

Cumhuriyet gazetesi web sitesinde darbe girişimi haberlerinde ilk gün yüzde 75.93 gibi baskın bir oranla şiddet teması öne çıkarken bunu yüzde 12.96 ile terör, yüzde 7.41 ile demokrasi, yüzde 1.85 ile din ve yine yüzde 1.85 ile milliyetçilik takip etmiştir. İlk gün ekonomi temalı bir haber yayımlanmamıştır.

İkinci güne yani 16 Temmuz'a gelindiğinde ise Hürriyet Gazetesi web sitesindeki demokrasi teması yüzde 19.12'ye gerilerken şiddet teması yükselerek yüzde 51.54'e ulaşmıştır. Bunu yüzde 12.64 ile terör, yüzde 10.38 ile milliyetçilik, yüzde 4.07 ile din ve son olarak yüzde 2.25 ile ekonomi temaları takip etmiştir.

Milliyet Gazetesi web sitesinde ise ikinci gün şiddet temalı haberler yüzde 53.14 oranına gerilerken demokrasi ve terör vurgulu haberler artmaya başlamıştır. Demokrasi teması yüzde 14.99'a çıkarken terör teması yüzde 14.66'ya yükselmiştir. Ayrıca milliyetçilik temalı haberler yüzde 11.93 oranında, din temalı haberler yüzde 4.79 oranında ve ekonomi temalı haberler ise yüzde 0.5 oranında yer bulmuştur.

Cumhuriyet gazetesi web sitesinde de ikinci gün şiddet temalı haberlerde gerileme görülmüş ve oran hâlâ ikinci günün gazetedeki en yüksek oran1 olmakla beraber yüzde 49.83'e düşmüştür. Darbe girişimi konusu Cumhuriyet Gazetesi'nde ikinci gün demokrasi temasıyla 
yüzde 24.29 , terör temasıyla yüzde 13.39 , milliyetçilik temasıyla yüzde 7.36 , din temasıyla yüzde 4.02 ve ekonomi temasıyla yüzde 1.11 oranlarında haberleştirilmiştir.

Sabah Gazetesi'ne bakıldığında ise haberler 16 Temmuz'dan itibaren web sitesinde görülmeye başlanmıştır. Darbe girişimi haberleri şiddet olayları temasıyla yüzde 47.44 oranında yer almıştır. Terör teması yüzde 22.49 ile diğer gazetelere göre en yüksek oranla Sabah Gazetesi web sitesinde yer almıştır. Ardından demokrasi teması yüzde 15.14, milliyetçilik teması yüzde 11.14, din teması yüzde 3.56 ve ekonomi teması yüzde 0.22 oranında tespit edilmiştir.

Üçüncü gün yani 17 Temmuz'a gelindiğinde ise Hürriyet Gazetesi web sitesindeki demokrasi teması yüzde 11.97'ye gerilerken şiddet teması yükselerek yüzde 57.58'e ulaşmıştır. Bunu yüzde 13.88 ile terör, yüzde 8.00 ile milliyetçilik, yüzde 6.09 ile din ve son olarak yüzde 2.48 ile ekonomi temaları takip etmiştir.

Milliyet Gazetesi web sitesinde ise üçüncü gün çok büyük yükselme ve alçalmalar görülmemekle birlikte şiddet olayları teması ufak bir gerilemeyle yüzde 48.60'a inmiş, terör teması ise ufak bir yükselmeyle yüzde 17.24'e çıkmıştır. Bununla beraber demokrasi temalı haberler yüzde 15.20 oranında, milliyetçilik temalı haberler yüzde 11.71 oranında, din temalı haberler yüzde 6.18 oranında ve ekonomi temalı haberler ise yüzde 1.07 oranında yer bulmuştur.

Cumhuriyet Gazetesi web sitesinde üçüncü gün darbe girişimi haberleri şiddet olayları temasıyla yüzde 49.39 oranında yer bulurken bunu yüzde 20.08 ile demokrasi, yüzde 16.80 ile terör, yüzde 9.02 ile din, yüzde 4.1 ile milliyetçilik ve yüzde 0.61 ile ekonomi temaları takip etmiştir.

Sabah Gazetesi web sitesinde ise son gün terör temasında hafif bir yükseliş tespit edilmiş ve oran yüzde 26.11 'e çıkmıştır. Bunun haricinde hafif bir düşüş olmasına rağmen hâlâ şiddet olayları teması yüzde 41.70 oranıyla en üstte yer almıştır. Ayrıca demokrasi teması yüzde 15.68, milliyetçilik teması yüzde 9.69 , din teması yüzde 6.46 ve ekonomi teması yüzde 0.37 oranlarında tespit edilmiştir (Tablo 1).

Tablo 1: Darbe girişimi haberlerinde medyanın öne çıkardığı temalar

\begin{tabular}{|c|c|c|c|c|c|c|c|c|c|c|c|c|c|}
\hline \multirow{3}{*}{ TARIH } & \multirow{3}{*}{ MEDYA } & \multicolumn{12}{|c|}{ TEMALAR } \\
\hline & & \multicolumn{2}{|c|}{ DEMOKRASI } & \multicolumn{2}{|c|}{ ŞIDDET } & \multicolumn{2}{|c|}{ DiN } & \multicolumn{2}{|c|}{ TERÖR } & \multicolumn{2}{|c|}{ MiLLIYETÇİLIK } & \multicolumn{2}{|c|}{ EKONOMI } \\
\hline & & $N$ & $\%$ & $N$ & $\%$ & $N$ & $\%$ & $N$ & $\%$ & $N$ & $\%$ & $N$ & $\%$ \\
\hline \multirow{4}{*}{$\begin{array}{l}15 \\
\text { Temmuz }\end{array}$} & Hürriyet & 30 & 50,00 & 15 & 25,00 & 0 & 0,00 & 3 & 5,00 & 12 & 20,00 & 0 & 0,00 \\
\hline & Milliyet & 0 & 0,00 & 6 & 85,71 & 0 & 0,00 & 0 & 0,00 & 1 & 14,29 & 0 & 0,00 \\
\hline & Cumhuriyet & 4 & 7,41 & 41 & 75,93 & 1 & 1,85 & 7 & 12,96 & 1 & 1,85 & 0 & 0,00 \\
\hline & Sabah & 0 & 0,00 & 0 & 0,00 & 0 & 0,00 & 0 & 0,00 & 0 & 0,00 & 0 & 0,00 \\
\hline \multirow{4}{*}{$\begin{array}{l}16 \\
\text { Temmuz }\end{array}$} & Hürriyet & 348 & 19,12 & 938 & 51,54 & 74 & 4,07 & 230 & 12,64 & 189 & 10,38 & 41 & 2,25 \\
\hline & Milliyet & 363 & 14,99 & 1287 & 53,14 & 116 & 4,79 & 355 & 14,66 & 289 & 11,93 & 12 & 0,50 \\
\hline & Cumhuriyet & 350 & 24,29 & 718 & 49,83 & 58 & 4,02 & 193 & 13,39 & 106 & 7,36 & 16 & 1,11 \\
\hline & Sabah & 68 & 15,14 & 213 & 47,44 & 16 & 3,56 & 101 & 22,49 & 50 & 11,14 & 1 & 0,22 \\
\hline \multirow{4}{*}{$\begin{array}{l}17 \\
\text { Temmuz }\end{array}$} & Hürriyet & 169 & 11,97 & 813 & 57,58 & 86 & 6,09 & 196 & 13,88 & 113 & 8,00 & 35 & 2,48 \\
\hline & Milliyet & 283 & 15,20 & 905 & 48,60 & 115 & 6,18 & 321 & 17,24 & 218 & 11,71 & 20 & 1,07 \\
\hline & Cumhuriyet & 98 & 20,08 & 241 & 49,39 & 44 & 9,02 & 82 & 16,80 & 20 & 4,10 & 3 & 0,61 \\
\hline & Sabah & 170 & 15,68 & 452 & 41,70 & 70 & 6,46 & 283 & 26,11 & 105 & 9,69 & 4 & 0,37 \\
\hline
\end{tabular}

Temalara ilişkin analiz kapsamında yaşanan olayın haber değerinin yüksekliği olaya ilişkin 3 günde seçilen örneklemde 760 haberin yer alması ile de açıç̧a görülmektedir. Darbe girişimine ilişkin adı geçen, sözlerinden alıntı yapılan ana aktörlere bakıldığında 95 haber ile Cumhurbaşkanı Recep Tayyip Erdoğan sözlerinden en çok alıntı yapılan ulusal politik aktör olarak öne çıkarken, 147 aktör adı ile yabancı ülke temsilcileri ve devlet başkanlarının mesajlarına yer verilmiştir. 
Tablo 2: Medya kuruluşlarının kaynak gösterdiği aktörler

\begin{tabular}{|c|c|c|c|c|c|}
\hline Aktörler & Cumhuriyet & Hürriyet & Milliyet & Sabah & Toplam \\
\hline RTE Cumhurbaşkanı & 21 & 23 & 27 & 24 & 95 \\
\hline B. Yıldırım/Başbakan & 11 & 13 & 8 & 5 & 37 \\
\hline Bakanlar/AKP & 18 & 15 & 29 & 16 & 78 \\
\hline Siyasi Partiler & 11 & 10 & 25 & 9 & 55 \\
\hline Yabancı Politikacı/bürokratlar & 23 & 49 & 64 & 11 & 147 \\
\hline $\begin{array}{l}\text { Genelkurmay Başkanı/ } \\
\text { rütbeli asker }\end{array}$ & 20 & 15 & 18 & 5 & 58 \\
\hline Tutuklanan rütbeli askerler & 23 & 33 & 20 & 33 & 109 \\
\hline Medya & 23 & 11 & 13 & 16 & 63 \\
\hline Vali & 6 & 12 & 12 & 6 & 36 \\
\hline $\begin{array}{l}\text { Cumhuriyet Savcılığı/ } \\
\text { Danıştay }\end{array}$ & 12 & 13 & 22 & 11 & 58 \\
\hline Diyanet/MiT/YÖK/bürokrat & 5 & 8 & 9 & 7 & 29 \\
\hline Belediye Başkanı & 6 & 6 & 7 & 4 & 33 \\
\hline F. Gülen & 7 & 1 & 4 & 9 & 21 \\
\hline STK & 16 & 2 & 0 & 5 & 23 \\
\hline Vatandaş & 6 & 10 & 19 & 4 & 39 \\
\hline $\begin{array}{l}\text { Ekon. aktörler } \\
\text { (şirket ve çıkar grupları) }\end{array}$ & 19 & 34 & 4 & 5 & 62 \\
\hline Spor kulübü & 6 & 3 & 0 & 12 & 21 \\
\hline Yabancı medya kuruluşları & 10 & 29 & 18 & 2 & 59 \\
\hline Uzman ve akademisyenler & 2 & 2 & 2 & 1 & 7 \\
\hline $\begin{array}{l}\text { Diğer (TBMM, sanatçı, } \\
\text { PKK vb.) }\end{array}$ & 8 & 3 & 5 & 3 & 19 \\
\hline
\end{tabular}

Tutuklanan, gözaltına alınan ya da suçlanan askerlere ilişkin 109 aktör adının geçmesi de ikinci önemli aktör kategorisinin suçlanan rütbeli askerler olduğunu göstermektedir. Yine bu konuda farklı ideolojik eğilimdeki gazetelerin farklı editoryal kararlar aldığı görülmektedir. Cumhuriyet dışındaki diğer üç gazete tutuklanan rütbeli askerlerin listeler halinde isimlerine "darbecilerin tam listesi” başlığ ile geniş yer vermiş, özellikle Hürriyet gazetesi yaşanan darbe girişimi sırasında yaşamını yitiren polisleri daha dramatik haberleştirmeye dönük bir editoryal yayın politikası izlemiştir. Haber metninde şehit ifadesinin kullanımı da Hürriyet ve Milliyet gazetelerinde sıklıkla tercih edilirken bu ifadenin kullanımı en az olarak Cumhuriyet gazetesinde görülmüştür. Hürriyet gazetesi haberlerinde özellikle darbe gününün tekrar tekrar kronolojik olay sırasıyla verilmesi de konunun okuyucunun belleğinde taze tutulması adına izlenen bir başka haberleştirme pratiği ve yine bir editoryal karar sonucu olduğuna işaret etmektedir.

Yerli ve yabancı medya organlarının haberlerde sıklıkla yer alması özellikle bu olay bağlamında haber kaynağının önemli olduğunu bize göstermiş ve doğru habercilik yapmak adına medya kuruluşlarının ve gazetecilerin sıklıkla adının geçmesine neden olmuştur. Bu bulgu, yaşanan olaya ilişkin hassasiyeti göstermektedir. Vali, bakanlar, Diyanet, MİT gibi kuruluşların beklenen aktör kategorisi olduğu göz önüne alındığında 58 aktör olarak Cumhuriyet savcılığının adı geçmese de aktör kategorisi olarak sıklıkla yer verildiği göze çarpmaktadır.

Sivil toplum kuruluşları kamu otoriteleri, siyasal aktörler kadar etkin olmamış ve sadece 23 haberde yer almıştır. Siklıkla Cumhuriyet gazetesinde yer verilmiş (16 aktör), Milliyet gazetesinde ise hiç yer verilmemiştir. Sivil toplum aktörleri kadar etkili bir aktör grubu yaklaşık benzer sayıda 
toplam 21 aktörle haberlerde yer alan spor kulübü temsilcisi ya da yöneticileridir. Sivil toplum kuruluşları yerine ekonomik aktör olarak kodlanan çıkar gruplarının temsili süreçte 62 aktörle daha etkin varlık göstermiştir. Ekonomik aktörler özellikle TÜSİAD, TOBB gibi ekonomik çıkar gruplarının açıklamalarda bulunduğu, sivil toplum adına ekonomik aktörlerin söz söylediği görülmektedir. Yine siyasi aktörlerin yoğunlukla temsil edildiği, uzman ve akademisyenlerin ise sadece 7 aktörle yer verildiği bir başka bulgudur. Terör eylemine ilişkin Fetullah Gülen'in sözleri ve adına 21 haberde yer verirken basın kuruluşları bu konuda farklı politika izlemeyi seçmiştir. Sabah ve Cumhuriyet 7 ve 9 haberde yer verirken Hürriyet gazetesi sadece 1 haberle aktörü meşru kılmamaya çalışmakta, Milliyet ise 4 haberle en az sayıda haberleştirmektedir. Haber içeriklerine bakıldığında Sabah ve Cumhuriyet gazetelerinde F. Gülen'in açıklamaları ve suçsuz olduğuna ilişkin kendi iddiaları haber metninde yer alırken Milliyet ve özellikle Hürriyet gazetelerinde çok az sayıda haberde sadece referans olarak adına yer verildiği, sözlerinden alıntı yapılmadığ 1 görülmektedir. Medyanın böylesi bir yok sayma yolunu tercih etmesinde özellikle darbe girişimi sırasında Hürriyet gazetesine düzenlenen saldırının da etkili olduğu düşünülebilir.

\section{Sonuç ve Değerlendirme}

İlk iki araştırma sorusu medyanın darbe girişimini haberleştirirken konuyu hangi temalar çerçevesinde ön plana çıkardığı ve farklı ideolojilere sahip medya kuruluşlarının darbe girişimini farklı bakış açılarıyla haberleştirip haberleştirmediğini merak etmekteydi. Analiz sonuçlarını öncelikle bu ilk iki araştırma sorusu üzerinden değerlendirmek gerekirse en temel üç temanın tüm gazete web sitelerinde baskın olduğu görülmektedir. Aynı zamanda ilk gün hariç bu dört farklı gazetenin benzer temaları ön plana çıkardığı da göze çarpmaktadır. Darbe girişimi haberlerinin dört gazetede de yoğun bir şekilde şiddet temasıyla yer bulduğu göze çarpmaktadır. Sadece Hürriyet Gazetesi ilk gün demokrasi temasına en büyük önemi atfederken diğer iki gün şiddet temasını öne çıkarmıştır. Milliyet, Cumhuriyet ve Sabah'ta ise 3 günün tamamında birinci sırada şiddet temasının görüldüğü tespit edilmiştir. Yine haberlerde demokrasi ve terör vurgusuna da sıklıkla rastlanmış, ikinci ve üçüncü sıralarda bu iki tema özellikle öne çıkmıştır. Terör temasını en yüksek oranda kullanan gazetenin ise hükümete yakınlığıyla bilinen Sabah Gazetesi olduğu gözlenmiştir. Milliyetçilik teması bu üç temanın ardından gelmekle beraber yine yüksek oranlarda haberlerin temasını oluşturmuştur. En az görülen temalar ise din ve özellikle de ekonomi olmuştur. Bu iki temanın diğer temaların gölgesinde kaldığı görülmektedir. Dolayısıyla darbe girişimiyle ilgili en yoğun haber geçilen 15-17 Temmuz arasındaki 3 günün şiddet, demokrasi ve terör üçgeninde ön plana çıkarıldığı gözlenmiştir. Ayrıca farklı ideolojilere sahip olmalarına rağmen bu dört gazetenin web sitesinde ilk gün hariç genellikle her temanın birbirine yakın oranlarda ön plana çıtı̆̆g gözlenmiştir. İlk gün olan 15 Temmuz'da ise Hürriyet daha çok demokrasi temasına odaklıyken Milliyet ve Cumhuriyet'in şiddet teması çerçevesinde olaylara yer verdiği ortaya çıkmıştır. Yine teröre vurgu daha çok Cumhuriyet'te gözlenirken milliyetçiliğe olan vurgu ise Hürriyet ve Milliyet'te dikkat çekmektedir. Hürriyetin haber tonunda yaşanan demokrasi vurgusundan terör ve şiddet vurgusuna keskin dönüşün gazeteye ve bağlı kuruluşlarına yapılan darbeci askerlerin baskını ile ilişkili olduğu da söylenebilir. Medyanın direkt olarak yaşadığı ve deneyimlediği şiddet olayı onun editoryal kararlarını keskinleştirmiş olabileceğini düşündürmektedir.

15 Temmuz darbe girişiminin terör ve şiddet temalarında yoğun olarak haberleştirilmesinin bir diğer nedeni de yaşanan olayın ülke tarihinde daha önce başarılı ve başarısız birden çok kez deneyimlenmiş olmasına karşın bu kadar şiddetin ilk kez gösteriliyor, yaşanıyor ve normalleştiriliyor olmasıdır. Hükümet yetkililerinden, politik seçkinlere tüm toplum eşik bekçilerinin bu olayın karşısında şiddet kullanılması gerektiğine ilişkin ifadeleri şiddeti olağanlaştırmış ve hatta normalleştirmiştir.

Terör farklı coğrafyalarda çeşitli şekillerde tanımlanırken akademik alanda da yine vurguların farklılaştığı tanımlamalar yapılmaktadır. Akademik yazında teröre ilişkin 109 tanımı inceleyen Jackson ve diğerleri $(2011,104)$ terörü "Bireyler, örgüt ya da hükümet aktörlerinin, 
kriminal ya da politik amaçlarla, tekrarlanan şiddet ve korku içeren davranışların seçilen belli bir gruba ya da rastgele halka uygulanarak mesaj oluşturulmasıdır" şeklinde tanımlar. Terör organizasyonu ile kurbanları arasında, korku ve şiddet içeren bir iletişim biçimi olarak tanımlanan terör eyleminde ana amaç, hedef kitleyi, isteği ve eylemi ilginin odağına yerleştirmek ve propaganda yapmaktır (Schimid ve Jogman, 1988; Jackson ve diğerleri, 2011). Tanımlamalardan yola çıktığımızda terör eylemi, genelde sıradan halkı hedef almakta, sivillerin kurban olarak seçilmesiyle geniş halk kitlesini etkilemekte ve etkilenen halkta çözülme ya da itaat sonuçlarına yol açmaktadır. İşte bu noktada terör eylemi, kitle iletişim araçlarına yani medya ilgisine ihtiyaç duymaktadır. Bu bağlamda bakıldığında 15 Temmuz darbe girişimi sürecinde siyasi figürlerin kullandığı dil ve tanımlamalarla medyanın kullandığ 1 dil ve tanımlamalar örtüşerek bu girişim terör olayı olarak adlandırılmıştır.

Yine çalışmanın aktörlere ilişkin bulguları da medyanın tıpkı terör eylemlerinde olduğu gibi politik ve yasa koyucuların resmî açıklamalarına sıklıkla yer verdiğini göstermektedir (Melek ve Toker, 2016). Cumhurbaşkanı Recep Tayyip Erdoğan darbe girişimine ilişkin en çok adı geçen, sözlerinden alıntı yapılan ulusal politik aktör olmuştur. Beklenenden daha fazla sayıda yabancı ülke temsilcileri ve devlet başkanlarının mesajlarına yer verilmiş ve olayın uluslararası arenada yarattığı etkinin büyüklüğüne vurgu yapılmıştır. Yabancı ülkeleri temsilen aktör adları ve mesajlarından kısa alıntılarla konuya ilişkin mesajlar verilmiş, öneminin altı çizilmiştir. Avrupa Birliği, NATO, BM gibi uluslararası ve ulus üstü örgütlerin dış ilişkiler temsilcileri veya genel sekreterlerinin mesajlarına da yer verilerek konunun uluslararası gündemdeki yeri habere yansıtılmıştır. Özellikle Hürriyet ve Milliyet gazetesinin diğer iki gazeteden çok daha fazla sayıda yabancı aktöre yer vermesi, olayın uluslararası arenada da etkili olduğunun medya tarafindan göstermeye çalışma çabası olarak yorumlanabilir. Basın, ideolojik eğilimine bağlı olarak, haber içerisinde yabancı aktörlere ve açıklamalarına da sıklıkla yer vermiş ve olayın etkisini yabanc1 aktörlere yer vererek de okuyucularına duyurmuştur.

Diğer önemli aktör kategorisi olan tutuklanan, gözaltına alınan ya da suçlanan askerlere ilişkin farklı ideolojik eğilimdeki gazetelerin farklı editoryal kararlar aldığı görülmüştür. Hürriyet gazetesine darbe girişimi sırasında baskın yapılması gazetenin editoryal kararlarını da etkilediği görülmüş, tutuklanan askerlerin tam listesini yayınlama, askerlerin özgeçmişlerine yer verme, şehit haberlerinde daha dramatik bir dil kullanma, darbe gününün kronolojik olay sırasını birden fazla sefer haberleştirme gibi yöntemlerle haberlere de yansıtılmıştır. Örnek olması bakımından Hürriyet gazetesinde darbe girişimi ve yaşanan olaylara ilişkin daha dramatik ifadeler kullandığ haberde geçen ifade ve başlıklar şu şekilde yer almıştır:

"Darbeciler halkın arasına karışmaya çalışıyor!", "Türkiye tarihi bir geceyi geride bıraktı", "Gün 1şırken darbe girişiminde bulunanların başarısızlığa uğradığı ortaya çıktı", "Dünya Türkiye'yi ayağa kaldıran geceyi böyle gördü”, "İște o isimler", "İkiz polisler birlikte şehit düştü”, "Mermisi biten polislerin yardımına vatandaşlar koştu", "Gözaltındaki erler gözyaşlarına boğuldu" (16 Temmuz, Hürriyet)."Silah zoruyla engellenen manşet”, "Komiser Gülşah da şehit oldu”, "Elazığ’a şehit ateşi”, "Hürriyet’e ateş”, "İşte darbecilerin öldürdüğü Serhat Önder'in son sözleri... ", "Silahların gölgesinde", "İşte şu ana kadar yaşananlar", "İşte darbe girişiminin arkasındakiler!", "Cumhurbaşkanı'nın uçağı darbeci F16'ları böyle atlattı", "İhanet en yakınlarından geldi”, "Denizlili işadamı ailesiyle dehşeti yaşadı", "Cumhurbaşkanı Erdoğan gözyaşlarına boğuldu" (17 Temmuz, Hürriyet).

Olayın terör, şiddet ve tutuklamalar içermesi nedeniyle gündelik haber kaynağı olarak çok sık öne çıkarılmayan Cumhuriyet savcılığının aktif bir aktör olarak savcıların isimlerine yer vermeden kaynak gösterildiği saptanmıştır.

Sivil toplum kuruluşlarına çok az sayıda aktörle neredeyse spor kulüp aktörleri kadar yer verilmesi konuya ilişkin toplumsal refleksin oluşturulamadığ 1 , henüz toplumsal travma aşamasında olunduğunu göstermektedir. Sivil toplum kuruluşları arasında da ezici çoğunlukla Türkiye Gazeteciler Sendikası, Türkiye Gazeteciler Cemiyeti (TGC) gibi basın örgütlerine 
ve açıklamalarına yer verilmiştir. Özellikle Cumhuriyet gazetesinde daha yoğunlukla olmak üzere medya kuruluşlarından alınan haberlere titizlikle ve referans kullanılarak yer verilmesi, medyanın bir aktör kategorisi olarak yer almasına neden olmuştur. (Örneğin, Reuters Haber Ajans1, CNN Türk, serbest gazeteci Neyran Elden, TRT, The Independent gibi).

İlk üç gün boyunca yerli ve yabancı siyasi aktörlerin öne çıktı̆̆ı, ulusal ve uluslararası medya kuruluşlarının, gazetecilerin kaynak olarak gösterildiği ve resmi kaynakların ön plana çıkarıldığı bir haberleştirme pratiği gözlenmiştir. Basın uyguladığı kaynak gösterme konusundaki genel tavrı yerine çok daha titiz, sorgulayıcı bir tavır sergilemiş ve doğru olmayan bilginin dolaşımına izin vermemek adına olayları medya kuruluşlarına, gazetecilerin adlarına ya da resmi aktörlere dayandırarak haberleştirmiştir.

\section{KAYNAKÇA}

Alexa. (t.y.). Erişim: 15 Temmuz 2016, http://www.alexa.com/topsites/countries/TR

Anderson, A. J. (1986). Communication Research: Issues and Methods. New York:McGrawHill.

Berelson, B. (1952). Content Analysis in Communication Research. Glencoe:The Free Press Publishers.

Chernov, G., Valenzuela S. and McCombs, M. (2011). An experimental comparison of two perspectives on the concept of need for orientation in agenda-setting theory. Journalism and Mass Communication Quarterly,88(1), 142-155.

Cohen, B. C. (1963). The press and foreign policy. Princeton, N. J: Princeton University Press.

Duverger, M. (1965). Diktatörlük Üstüne (B. Tanör, Çev.). İstanbul: Dönüm Yayınevi. (1961).

Efkan Ala: Tutuklu sayıs1 16 bin 899. (11 Ağustos 2016). Erişim: BirGün, http://www.birgun. net/haber-detay/efkan-ala-tutuklu-sayisi-16-bin-899-123758.html

Entman, R. M. (1993). Framing: Toward Clarification of a Fractured Paradigm.Journal of Communication, 43, 51-58.

Gitlin, T. (1980). The Whole World Is Watching: Mass Media in the Making \& Unmaking of the New Left. Berkeley, CA: University of California Press.

Goffman, E. (1974). Frame Analysis: An Essay on the Organization of Experience. New York: Harper and Row.

Güler, U. (2006). Türkiye'de Siyasal Bir Aktör Olarak Ordu. Yüksek lisans tezi, Dokuz Eylül Üniversitesi, İzmir.

Huntington, S. P. (1969). Political Order in Changing Societies. New Haven: Yale University Press.

Jackson, R., Jarvis, L., Gunning, J. and Symth, M. B. (2011). Terrorism: A Critical Introduction. England: Palgrave.

Kalaycıŏlu, E. (2008).Türkiye'de Demokrasi’nin Pekişmesi: Bir Siyasal Kültür Sorunu. Ankara: Yetkin Yayınevi. 
Kim, S. H., Scheufele, D. A. and Shanahan, J. (2002). Think about it this way: Attribute agendasetting function of the press and the public's evaluation of a local issue.Journalism \& Mass Communication Quarterly, 79(1), 7-25.

Kiousis, S., Bantimaroudis, P. and Ban, H. (1999). Candidate image attributes: Experiments on the substantive dimension of second level agenda setting. Communication Research, $26(4), 414-428$.

Kushin, M., J. (2010). Tweeting the issues in the age of social media? Intermedia agenda setting between the New York Times and Twitter. Doktora tezi, Pullman, WA: Washington State University.

Lee, G. (2005). Agenda setting effects in the digital age: Uses and effects of online media. Doktora tezi, The University of Texas at Austin, United States.

Lowe, W. (2015). Yoshikoder: Cross-platform multilingual content analysis. Java software version 0.6.5.Erişim: 21 Kasım2016, http://www.yoshikoder.org

Matthes, J. (2008). Need for orientation as a predictor of agenda-setting effects: Causal evidence from a two-wave panel study. International Journal of Public Opinion Research, 20(4), 440-453.

McCombs, M. (2002). The agenda-setting role of the mass media in the shaping of public opinion [Bildiri], Mass Media Economics 2002 Conference, London School of Economics '02, London.

McCombs, M. (2004). Setting the Agenda: The Mass Media and Public Opinion. Malden, MA: Blackwell.

McCombs, M. (2005). A look at agenda-setting: Past, present and future. Journalism Studies, 6(4), 543-557.

McCombs,M. and Bell, T. (1996). The agenda-setting role of mass communication. M. B. Salwen and D. W. Stacks (Ed.). An Integrated Approach to Communication Theory and Research (s. 93-110). Mahway, NJ: Lawrence Erlbaum.

McCombs, M., Lopez-Escobar, E. and Llamas, J. P. (2000). Setting the agenda of attributes in the 1996 Spanish general election. Journal of Communication, 50, 77-92.

McCombs,M. and Shaw, D. L. (1972). The Agenda-Setting Function of Mass Media. Public Opinion Quarterly, 36, 176-187.

McCombs,M. and Shaw, D. L. (1993). The Evolution of Agenda-Setting Research: Twenty-Five Years in the Marketplace of Ideas. Journal of Communication, 43, 58-67.

Melek, G. (2015). Medya Arası Gündem Belirleme Kuramı Çerçevesinde Hürriyet ve Twitter Üzerine Bir Çalışma. Doktora tezi, Ege Üniversitesi, İzmir.

Melek, G. ve Toker, H. (2016). 2016 Sultanahmet Terör Eylemi: Yerelin Küreselleşmesi. Selçuk İletişim, 9(3), 178-203.

Özkan, A. B. (27 Temmuz 2016). FETÖ’nün Darbe Girişiminde Şehit Sayısı 246’ya Yükseldi. Erişim: Anadolu Ajans1, http://archive.is/SPxkp\#selection-6215.785-6215.802

Reese, S. and Danielian, L. (1989). Intermedia Influence and the Drug Issue: Converging on Cocaine. P. Shoemaker (Ed.). Communication Campaigns about Drugs: Government, Media and the Public. (s. 29-46). Hillsdale, NJ: Lawrence Erlbaum. 
Roberts, M., Wanta, W. and Dzwo, T. (2002). Agenda Setting and Issue Salience Online. Communication Research, 29(4), 452-465.

Ryan, C. (1991).Prime Time Activism: Media Strategies for Grassroot Organizing.Boston, MA: South End.

Scheufele, D. A. (1999). Framing as a Theory of Media Effects.Journal of Communication,49, 103-122.

Scheufele, D. A. and Tewksbury, D. (2007). Framing, Agenda Setting and Priming: The Evolution of Three Media Effects Models.Journal of Communication, 57, 9-20.

Schmid, A. P. and Jogman, A. J. (1988). Political Terrorism: A New Guide to Actors, Authors, Concepts, Data bases, Theories, and Literature. Amsterdam: Transactions Book.

Severin, W. J. and Tankard, J. W. (2001). Communication theories: Origins, methods, and uses in the mass media. New York: Addison Wesley Longman.

Takeshita, T. (2006). Current Critical Problems in Agenda-Setting Research. International Journal of Public Opinion Research, 18(3), 275-296.

Tankard, J., Hendrickson, L., Silberman, J., Bliss, K. and Ghanem, S. (1991). Media Frames: Approaches to Conceptualization and Measurement [Bildiri], the Annual Convention of the Association for Education in Journalism and Mass Communication '91, Boston, MA.

Weaver, D. (1977). Political issues and voter need for orientation. D. Shaw andM. McCombs (Ed.). The emergence of American political issues (s. 107-119). St. Paul, MN: West.

Weaver, D. H. (2007). Thoughts on Agenda Setting, Framing, and Priming.Journal of Communication, 57, 142-147.

Weberling, B. (2012). Framing breast cancer: Building an agenda through online advocacy and fundraising. Public Relations Review, 38(1), 108-115. 